\title{
Apoptosis and metastasis inhibitory potential of pineapple vinegar against mouse mammary gland cells in vitro and in vivo
}

Nurul Elyani Mohamad', Nadiah Abu², Swee Keong Yeap ${ }^{3}$, Kian Lam Lim', Muhammad Firdaus Romli', Shaiful Adzni Sharifuddin ${ }^{5}$, Kamariah Long ${ }^{5}$ and Noorjahan Banu Alitheen ${ }^{1,6^{*}}$ (i)

\begin{abstract}
Background: Plant-based food medicine and functional foods have been consumed extensively due to their bioactive substances and health-beneficial effects. Vinegar is one of them due to its bioactivities, which confers benefits on human body. Our previous study has produced pineapple vinegar that is rich in gallic acid and caffeic acid via 2 steps fermentation. There are many evidences that show the effectiveness of these resources in inhibiting the proliferation and metastasis of the cancer cells through several mechanisms.

Methods: Freeze-dried pineapple vinegar was evaluated for its in vitro apoptosis and metastasis inhibitory potential using MTT, cell cycle, Annexin V and scratch assays. The in vivo test using BALB/c mice challenged with $4 \mathrm{T1}$ cells was further investigated by pre-treating the mice with 0.08 or $2 \mathrm{ml} / \mathrm{kg}$ body weight of freshly-prepared pineapple vinegar for 28 days. The tumor weight, apoptotic state of cells in tumor, metastasis and immune response of the untreated and pineapple vinegar treatment group were evaluated and compared.

Results: From the in vitro study, an $\mathrm{IC}_{50}$ value of $0.25 \mathrm{mg} / \mathrm{mL}$ after $48 \mathrm{~h}$ of treatment was established. Annexin V/PI and scratch closure assays showed that pineapple vinegar induced $70 \%$ of cell population to undergo apoptosis and inhibited $30 \%$ of wound closure of $4 \mathrm{~T} 1$ cells. High concentration of pineapple vinegar ( $2 \mathrm{ml} / \mathrm{kg}$ body weight) led to the reduction of tumor weight and volume by $45 \%$ as compared to the untreated 411 -challenged mice. This effect might have been contributed by the increase of T cell and NK cells population associated with the overexpression of IL-2 andIFN- $\gamma$ cytokines and splenocyte cytotoxicity. Furthermore, fewer instances of metastasis events were recorded in the pineapple vinegar treatment group and this could be explained by the downregulation of inflammation related genes (iNOS, NF-kB and COX2), metastasis related genes (iCAM, VEGF and MMP9) and angeogenesis related genes (CD26, TIMP1, HGF, MMP3, IGFBP-1 and IGFBP-2).
\end{abstract}

Conclusion: The ability of pineapple vinegar to delay cancer progression portrayed its potential as chemopreventive dietry intervention for cancer therapy.

Keywords: Mammary gland cancer, Pineapple vinegar, In vitro, In vivo

\footnotetext{
* Correspondence: noorjahan@upm.edu.my

${ }^{1}$ Department of Cell and Molecular Biology, Faculty of Biotechnology and

Biomolecular Science, Universiti Putra Malaysia (UPM), 43400 Serdang,

Selangor, Malaysia

${ }^{6}$ Institute of Bioscience, Universiti Putra Malaysia (UPM), 43400 Serdang,

Selangor, Malaysia

Full list of author information is available at the end of the article
}

(c) The Author(s). 2019 Open Access This article is distributed under the terms of the Creative Commons Attribution 4.0 International License (http://creativecommons.org/licenses/by/4.0/), which permits unrestricted use, distribution, and reproduction in any medium, provided you give appropriate credit to the original author(s) and the source, provide a link to the Creative Commons license, and indicate if changes were made. The Creative Commons Public Domain Dedication waiver (http://creativecommons.org/publicdomain/zero/1.0/) applies to the data made available in this article, unless otherwise stated. 


\section{Background}

Cancer occurs when the growth of tissues is uncontrollable due to the unchecked proliferation of abnormal cells with the ability to invade other tissues [1]. Even though the numbers of cases have dropped each year, cancer is still one of the leading causes of death worldwide with breast cancer as the most common type of cancer in women [2]. Many chemotherapy and hormone-therapy drugs have been developed to cure or delay the progression of cancer; however,these drugs also bring about detrimental side effects [3]. Thus, the discovery of a potential chemo-preventive dietary intervention is welcomed [4].

Plants have the potential to rival the conventional treatments in treating cancer as they contain active compounds, which will work well as therapeutic agents andthere are vast historical records detailing the use of plants preparation in folk medicine $[5,6]$. The ability of the natural resources to act as the chemo-preventive agents without harming the healthy tissues opens up a new field to be researched on [7]. The anti-inflammatory and anti-cancer effects of some bioactive compounds present in plants were identified and proven clinically [8]. Besides that, there have been initiatives to process them into supplements and health drinks, which will enable consumers to include them in their daily diet [9].

Pineapple (Ananas comosus) has been utilized clinically in different situations such as to treat burn, smoothen the bowel movement, and improve the immune system [10]. On the other hand, vinegar has been consumed for ages and its properties as anti-inflammation, anti-glycemic, and anti-hypertensive are extensively well known [11]. In the previous study, it was reported that pineapple vinegar was able to reverse the liver damage caused by an overdose of paracetamol in mice due to its anti-oxidant and antiinflammatory effects [12]. To date, some studies have proven the in vitro and in vivo anti-tumor effect of several types of vinegars [13-15]. Nevertheless, no research has yet to be carried out to evaluate the possibility of using pineapple vinegar for cancer treatment, especially on breast cancer. Previously, we have reported that pineapple vinegar was rich in gallic acid, caffeic acid and several other phenolic acids [12]. There are many reports that have indicated the role of phenolic acids as onco-protective agent [16-18]. Thus, the in vitro study on the cytotoxic effect of pineapple vinegar on $4 \mathrm{~T} 1$ breast cancer cell was performed. Since positive results were observed, the pineapple vinegar was further investigated in vivo on the murine model. Through this study, the potential of pineapple vinegar as chemopreventive and dietry intervention for cancer therapy was recognized.

\section{Methods}

\section{Preparation of pineapple vinegar}

Pineapple vinegar was prepared according to the previous study [12]. In brief, pineapple juice underwent double fermentation process, first by anerobic fermentation using Saccharomyces ceverisae 7013 INRA to produce alcohol followed by aerobic fermentation using Acetobacteracetii vat Europeans for another 4 weeks, which produced $6-8 \%$ of acetic acid at the end of the processes. Then, the sample was left to mature at room temperature for 4 weeks. The final product, the liquid pineapple vinegar,will have a pungent smell with a slightly brownish color. The sample was then kept at $4{ }^{\circ} \mathrm{C}$ for further use.

\section{In vitro cytotoxicity study}

For the in vitro study, it is necessary to freeze dry the sample. The pineapple vinegar prepared in previous step was extracted using ethyl acetate (319902, Sigma Aldrich, USA) following the protocols described by Nishidai (2000) with slight modifications [19]. Briefly, 1.5 L of pineapple vinegar were gently mixed with ethyl acetate at room temperature at a ratio of 1:1 (v:v). The mixture was incubated for 5 min to allow the phases to separate. The ethyl acetate fraction (top layer) was separated from the immiscible layer using separatory funnel. The fraction was then evaporated using rotary evaporator (Büchi Rotavapor R-215, Switzerland). The extracted pineapple vinegar was then dissolved with cell culture media at a desired concentration.

\section{Cell culture}

Mouse mammary gland cells, 4 T1 (CRL-2539, ATCC, USA), human mammary gland cells MDA-MB-231 (HTB-26, ATCC, USA) and murine leukemia virus induced YAC-1 (TIB-160, ATCC, USA) were purchased from the ATCC collection and cultured in RPMI 1640 (R8758, Sigma Aldrich, USA) containing 10\% fetal bovine serum (FBS) (26140, Gibco, USA). The cells were grown at $37^{\circ} \mathrm{C}$ in a humidified incubator with $5 \% \mathrm{CO}_{2}$.

\section{3-(4,5-Dimethylthiazol-2-yl)-2,5-diphenyltetrazolium bromide (MTT) assay}

The cytotoxicity of pineapple vinegar was measured with the MTT assay. Briefly, 4 T1 and MDA-MB-231 cells (of $8.0 \times 10^{4}$ cells/well) were seeded on a 96-well plate. Twenty-four hours after initial seeding, a two-fold serial dilution of seven different concentrations (700.00, $350.00,175.00,87.50,43.75,21.88,10.94 \mathrm{mg} / \mathrm{mL})$ of pineapple vinegar was added into the plate. After $48 \mathrm{~h}$ of treatment, the cell viability was measured by adding $20 \mu \mathrm{L}$ of MTT solution $(5 \mathrm{mg} / \mathrm{mL})$ (475989, Merck, USA) in each well. After $3 \mathrm{~h}$ of incubation with the MTT solution, the solution was discarded and $100 \mu \mathrm{L}$ of DMSO (472301, Sigma Aldrich, USA) was added into 
the plate in order to solubilize the MTT crystals. The reading was taken after $30 \mathrm{~min}$ at the wavelength of 570 $\mathrm{nm}$ using enzyme-linked immunosorbent assay (ELISA) plate reader (Bio-tek Instruments, USA). The assay was done in triplicates. The cytotoxicity result was analyzed using the formula given below:

[Percentage of Cell Viability $=$ OD Sample $/$ OD control $\times 100 \%$ ]

From the MTT result, two inhibitory concentration (IC) values after $48 \mathrm{~h}$ of treatment for $4 \mathrm{~T} 1$ cells have been selected to be used in the following assays.

\section{Cell cycle analysis}

4 T1 cells were cultured at the concentration of $2.3 \times 10^{5}$ cells/well and were treated with pineapple vinegar at two different concentrations, namely; 0.25 $\mathrm{mg} / \mathrm{ml}$ and $0.32 \mathrm{mg} / \mathrm{mL}$ for $48 \mathrm{~h}$. After that, they were trypsinized before centrifuged at $2000 \mathrm{rpm}$ for $5 \mathrm{~min}$ and the pellet was collected and fixed with $70 \%$ ethanol for at least a week. On the respective day, the pellets were washed with $500 \mu \mathrm{L}$ of phosphate buffer saline (PBS) and treated with $10 \mu \mathrm{g} / \mathrm{mL}$ of RNAse and Triton-X 100 (X100, Sigma Aldrich, USA) before stained with $10 \mu \mathrm{g} / \mathrm{mL}$ of propidium iodide (PI) (P4170, Sigma Aldrich, USA). After 15 min of incubation, the cells were analyzed using a fluorescence-activated cell sorter (FACS) flow cytometry (Becton Dickinson, USA).

\section{Annexin $\mathrm{V}$ analysis}

The apoptotic state of the cells was determined using fluorescein isothiocyanate (FITC) Annexin-V Apoptosis detection kit (556547, BD Pharmingen, USA) and the assay was done according to the user guideline provided. In brief, 4 T1 cells $\left(2.3 \times 10^{5}\right.$ cells/well $)$ were treated with pineapple vinegar at the concentrations of $0.25 \mathrm{mg} / \mathrm{mL}$ and $0.32 \mathrm{mg} /$ $\mathrm{mL}$ for $48 \mathrm{~h}$. Then, the cells were double-stained with PI and FITC for $15 \mathrm{~min}$ in the dark and analyzed using a FACS-Calibur flow cytometer (Beckman Coulter, USA). The experiment was carried out in triplicates.

\section{In vitro scratch assay}

The assay was performed using the wound healing method as described in previous study [20]. In brief, 4 T1 cells were seeded on a 6 well plate and left overnight to full confluency. On the next day, with a sterile yellow tip, a linear scratch was introduced in the middle of the wells. Then, the old media was replaced with the new media containing different concentrations of pineapple vinegar. The closure rate of the scratch was observed and captured every few hours up to $24 \mathrm{~h}$ using a light microscope (Nikon, Japan).
The rate of wound closure was calculated using the following formula:

$$
\begin{aligned}
& \text { Percentage of scratch closure } \\
& =\frac{(\text { Area of wound at } 0 \text { hour }- \text { area wound at } n \text { hour })}{(\text { Area of wound at } 0 \text { hour })} \times 100 \%
\end{aligned}
$$

\section{The chemo-preventive experiment design}

The chemo-preventive effect of pineapple vinegar was evaluated using 4-6 weeks old BALB/c female mice with average weight of $20-22 \mathrm{~g}$. This study was approved by the Institutional Animal Care and Use Committees (IACUC) of UPM (UPM/IACUC/AUP-R097/2014). All animal procedures were performed strictly according to the protocol by the IACUC of UPM. The mice were randomly divided into 4 groups with 8 mice per group. The mice were acclimatized for one week $\left(22 \pm 1{ }^{\circ} \mathrm{C} ; 12\right.$-h dark/light cycle) and they were given distilled water and standard pellet diet ad libitum. Then, the mice were separated into groups (below) and pre-treated with either distilled water or pineapple vinegar for 6 weeks and post-treated for 4 weeks via oral gavage based on the course of time conducted during the pilot study. Two $\mathrm{ml} / \mathrm{kg} \mathrm{BW}$ was chosen as the highest concentration as it is the common maximum concentration used by all in vivo vinegar studies done previously while the $0.08 \mathrm{ml} /$ kg BW was calculated based on the common concentration of vinegar consumed by human (1 tablespoon of vinegar diluted in 1 glass of water).

Untreated (UT): Induced mice, given distilled water throughout the study (untreated);

Pineapple vinegar low concentration (PL): Induced mice, pretreated with pineapple vinegar $(0.08 \mathrm{ml} / \mathrm{kg}$ BW);

Pineapple vinegar high concentration $(\mathrm{PH})$ : Induced mice, pretreated with pineapple vinegar $(2 \mathrm{ml} / \mathrm{kg} \mathrm{BW})$.

At the end of 6th week, all mice were inoculated with the $4 \mathrm{~T} 1$ cells via subcutaneous (s.c) injection of $1 \times 10^{5}$ cells in $100 \mu \mathrm{L}$ PBS. The treatment continued for another 4 weeks. At the end of the experiment, all mice wereanesthetized with $2 \%$ isoflurane (1349014, Merck, USA) and sacrificed by cervical dislocation. Tumor, spleen and blood were collected from the mice prior to the following assays.

\section{Body weight and tumor weight analysis}

The body weights of the mice were measured once a week until the end of the study. Tumors were weighed and washed in PBS before they were chopped into smaller pieces and kept in liquid nitrogen for further use. 


\section{Immunophenotyping by flow cytometry}

Briefly, the harvested spleens were washed and meshed through $70 \mathrm{~mm}$ cell strainers (SPL, Korea) in PBS. The supernatants were centrifuged at $2000 \mathrm{rpm}$ for $15 \mathrm{~min}$ before the pellets were lysed using ammonium chloride $\left(\mathrm{NH}_{4} \mathrm{Cl}\right)$ buffer. Then, the splenocytes were stained with four different antibodies; CD3 (AB24948, Abcam, UK), CD4 (AB86859, Abcam, UK), CD8 (AB39850, Abcam, UK), NK1.1 (AB25352, Abcam, UK) and macrophage (AB105155, Abcam, USA) before they were subjected to flow cytometry analysis using a FACS Calibur flow cytometer (BD, USA).

\section{Terminal Deoxynucleotidyl transferase dUTP Nick end labeling (TUNEL) assay}

The TUNEL assay was carried out using the DeadEnd ${ }^{\mathrm{pm}}$ colorimetric TUNEL System (G7360, Promega, USA) according to the manufacturer's protocol. In brief, tumors were excised and embedded on slide. Then, the slides were deparaffinized in xylene twice for 5 min before they were rehydrated in decreasing concentrations of ethanol (100, 95, 85, 70 and 50\%) beforethey were washed in PBS. To detect apoptotic cells, the slides were fixed in $4 \%$ paraformaldehyde and permeabilized using proteinase $\mathrm{K}$ before they were fixed again in $4 \%$ paraformaldehyde. Later, the slides were then equilibrated using the equilibration buffer and labeled using terminal deoxynucleotidyl transferase (TdT). Next, the slides were blocked in hydrogen peroxide before being incubated with streptavidin horseradish peroxidase (HRP). The slides were then developed using 3,3'-Diaminobenzidine (DAB) and mounted in glycerol and they were viewed under a bright-field inverted microscope (Nikon, Japan). The degree of DNA fragmentation was measured based on the presence of dark brown cells (apoptotic cell indicator) against a light brown background.

\section{Metastasis analysis using clonogenic assay and bone marrow test}

The anti-metastatic potential of pineapple vinegar was investigated using clonogenic assay and bone marrow test. Briefly, the mice were sacrificed before their liver, spleen, lung and leg were removed under sterile condition, washed with PBS and were prepared according to the assays respectively. The clonogenic assay was done according to the previous study [19]. In brief, the liver, spleen and kidney were chopped into smaller pieces $\left(<1 \mathrm{~cm}^{3}\right)$. Then, each organ was incubated in PBS and collagenase D for $20-30 \mathrm{~min}$ at $37^{\circ} \mathrm{C}$ and the mixtures were mixed thoroughly every $5 \mathrm{~min}$. Next, the solution was passed through $70 \mathrm{~mm}$ cell strainer (SPL, Korea) and spun at $2000 \mathrm{rpm}$ for $10 \mathrm{~min}$. The pellet was then washed with PBS and resuspended in $10 \mathrm{ml}$ suspension medium (RPMI 1640, 10\% FBS, $1 \%$ penicillin-streptomycin, $60 \mu \mathrm{M}$ 6-thioguanine).
Six serial dilutions were made in 6-well plates and the plates were incubated for 10 days. On the 10th day, the plates were fixed with methanol and stained with crystal violet. The results were obtained by counting the colony by naked eyes.

The bone marrow-derived cell (BMDC) - cancer cell metastasis assay was done according to a previous study with slight modifications [21]. Briefly, the femurs were harvested and washed in PBS. Then, $100 \mu \mathrm{L}$ of PBS was used to flush out the bone marrow of femur and a smear was done by sliding the liquid onto the glass slides. The slides were air dried at room temperature for half an hour before they were fixed in methanol for another half an hour. Next, the fixed slides were stained with undiluted Giemsa solution (48900, Sigma Aldrich, USA) for $15 \mathrm{~min}$ before they were washed with distilled water for few times and leave to air dry overnight. The slides were viewed at 100x magnification under a light microscope (Nikon, Japan).

\section{Lactate dehydrogenase (LDH) Splenocyte cytotoxicity assay}

This assay was done according to the previous study [20]. The spleens from all treatment groups were harvested before they were meshed and incubated with YAC-1 cells overnight. CytoTox 96 nonradioactive cytotoxicity assay kit (G1780, Promega, USA) was used to determine the cytotoxicity activities. The splenocytes were seeded at the ratio of splenocytes (effector spontaneous) to YAC-1 cells (target spontaneous) being 2 to 1 and 5 to 1 . The cells were incubated for $24 \mathrm{~h}$ in a $90 \%$ humidified $37^{\circ} \mathrm{C}$ incubator supplemented with $5 \% \mathrm{CO}_{2}$. After $24 \mathrm{~h}$ of incubation, a lysis solution was added to the wells. After $45 \mathrm{~min}$, the media was removed and $50 \mu \mathrm{L}$ of the reconstituted substrate mix was added and it was incubated for $30 \mathrm{~min}$ at room temperature. After $30 \mathrm{~min}, 50 \mu \mathrm{L}$ of stop solution was added and the absorbance was taken at $490 \mathrm{~nm}$ using a $\mu$ quant microplate reader (Bio-Tek Instruments, USA). The percentage of cytotoxicity was calculated using the equation given in the manual protocol.

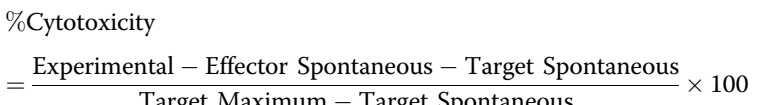

\section{Real time polymerase chain reaction (RT-PCR) analysis} Equal amounts of total ribonucleic acid (RNA) of tumor samples were extracted using RNeasy mini kit (74104, Qiagen,Germany) and reverse transcribed to complementary DNA (cDNA) using iScript ${ }^{\text {tm }}$ cDNA Synthesis Kit (1708890, Bio-Rad,USA). The cDNA was then subjected to the RT-PCR analysis using iQ5 RT-PCR machine (Bio-Rad, USA) and the results 
were analyzed using iQ5 Optical System Software. The primer sequences used in the study were given in Additional file 1: Table S1.

\section{Cytokine assay}

The blood was collected from each mouse using BD Microtainer Tubes (Becton Dickinson, USA) and spun at 14000 $\mathrm{rpm}$ for $15 \mathrm{~min}$ and kept in $-20^{\circ} \mathrm{C}$ until further use. On the respective day, the serums were diluted 10 times using assay diluent buffer and they are subjected to the following ELISA cytokine assays; interleukin-2 (IL-2) (DY402, R\&D Systems, USA), interleukin-1 beta (IL-1 1 )(DY401, R\&D Systems, USA), interleukin-10 (IL-10) (DY417, R\&D Systems, USA) and interferon gamma (IFN- $\gamma$ ) (DY485, R\&D Systems, USA). All assays were done according to the R\&D Systems Mouse Cytokine kit manual protocols (R\&D Systems, USA).

\section{Protein preparation from tumor}

The tumors were harvested, snapped freeze and kept in $-80^{\circ} \mathrm{C}$ until use. On the respective day, the tumors were weighed and meshed using a mortar and pestle with liquid nitrogen. Then, the tumors were lysed in radioimmunoprecipitation assay (RIPA) buffer $(150 \mathrm{mM}$ sodium chloride, $1.0 \%$ NP-40 or Triton X-100 $0.5 \%$ sodium deoxycholate, $0.1 \%$ sodium dodecyl sulfate (SDS) and 50 $\mathrm{mM}$ Tris, pH 8.0 mixed with protease inhibitor cocktail) (Pierce, Thermo Fisher Scientific, USA). The protein concentrations were measured using Bradford reagent (Bio-Rad, USA). Then, the protein samples were kept in $-80^{\circ} \mathrm{C}$ for further use.

\section{Western blot analysis}

By using SDS page, equal amounts of protein were separated and transferred to nitrocellulose membrane (PALL, USA). The membrane was then blocked with 5\% non-fat milk (NB0669, Biobasic, Canada) overnight. The next day, the membrane was washed with tris-buffered saline (TBS) and Polysorbate 20 (TBST) $(10 \mathrm{mM}$ Tris, $140 \mathrm{mMNaCl}, 0.1 \%$ Tween-20, $\mathrm{pH}$ 7.6) and incubated in primary antibody for $1 \mathrm{~h}$ at $4{ }^{\circ} \mathrm{C}$ followed by washing with TBST before it was incubated with appropriate secondary antibody for another hour. Then, it was washed again and incubated with HRP substrate for $10 \mathrm{~min}$ before it was viewed using a chemiluminescence imager (UVP, USA). Beta actin ( $\beta$-actin) (AB8226, Abcam, USA) was used as a housekeeping control. The results obtained were analyzed using Vision Work LS Analysis software (UVP, USA).

\section{Proteome profiler assay (angiogenesis)}

The effect of pineapple vinegar on the angiogenic process of $4 \mathrm{~T} 1$ cancer cells was investigated using proteome profiler kit (ARY015, R\&D System, USA).
Briefly, the membranes were blocked with blocking buffer while the protein samples were incubated with the detection antibody at room temperature for an hour. Next, the protein mixtures were transferred to the membrane and incubated at $4{ }^{\circ} \mathrm{C}$ overnight. On the next day, the membranes were washed three times using washing buffer and incubated with streptavidin-HRP for $30 \mathrm{~min}$. Lastly, the membranes were washed again 3 times before the substrate was added to develop chemiluminescence. The membranes were then viewed using Chemi Doc XRS (Bio-Rad).

\section{Statistical analysis}

All experiments were carried out in three biological replicate $(n=3)$. Quantitative data were expressed as mean \pm SD and were analyzed using one-way ANOVA, SPSS16. $P$ values of $<0.05$ were considered statistically significant.

\section{Results}

Pineapple vinegar inhibited the viability of $4 \mathrm{~T} 1$ cells in vitro

Colorimetric tetrazolium reduction test (MTT) was carried out to study the cytotoxicity of pineapple vinegar against the 4T1 and MDA-MB-231 breast cancer cell lines. The cytotoxicity effect was determined from the $50 \%$ inhibitory concentration $\left(\mathrm{IC}_{50}\right)$ and $75 \%$ inhibitory concentration $\left(\mathrm{IC}_{75}\right)$ at $48 \mathrm{~h}$ treatment. Pineapple vinegar showed $\mathrm{IC}_{50}$ values of $0.25 \pm 0.03$ and $0.27 \pm 0.02 \mathrm{mg} / \mathrm{mL}$ to 4 T1 and MDA-MB-231 triple negative cell lines at 48 h. In addition, the $\mathrm{IC}_{75}$ values were $0.32 \pm 0.02$ and $0.35 \pm 0.03 \mathrm{mg} / \mathrm{mL}$ to $4 \mathrm{~T} 1$ and MDA-MB-231 cells, respectively. Overall, the $\mathrm{IC}_{50}$ and $\mathrm{IC}_{75}$ value of pineapple vinegar on murine and human triple negative mammary gland cancer cells are similar and not significantly different $(p>0.05)$.

\section{Apoptosis induction analysis of pineapple vinegar treated $4 \mathrm{~T} 1$ cells}

The cell cycle regulation by pineapple vinegar was investigated using a cell cycle analysis. Figure 1a showed the normal distribution in the untreated $4 \mathrm{~T} 1$ cells (control) at $48 \mathrm{~h}$ treatment. As the concentration of the pineapple vinegar increased to $0.32 \mathrm{mg} / \mathrm{mL}$, the proportion of $\mathrm{S}$ phase increased to $26.37 \pm 0.84 \%$ as compared to the control $(23.66 \pm 0.55 \%)$. Sub G0/G1 phase marked a significant increase for treatment with pineapple vinegar $\left(\mathrm{IC}_{50}\right.$ at $11.46 \pm 0.35 \% ; \mathrm{IC}_{75}$ at $\left.13.46 \pm 0.60 \%\right)$ as compared to the control $(3.32 \pm 0.37 \%)$. These results suggest that the treatment with pineapple vinegar was able to inhibit the growth of $4 \mathrm{~T} 1$ cells through apoptosis by the significant increment in the percentage of cells in hypo diploid subG0/G1 population (2nDNA).

To further support the induction of apoptosis by pineapple vinegar, Annexin V assay was done and the results 


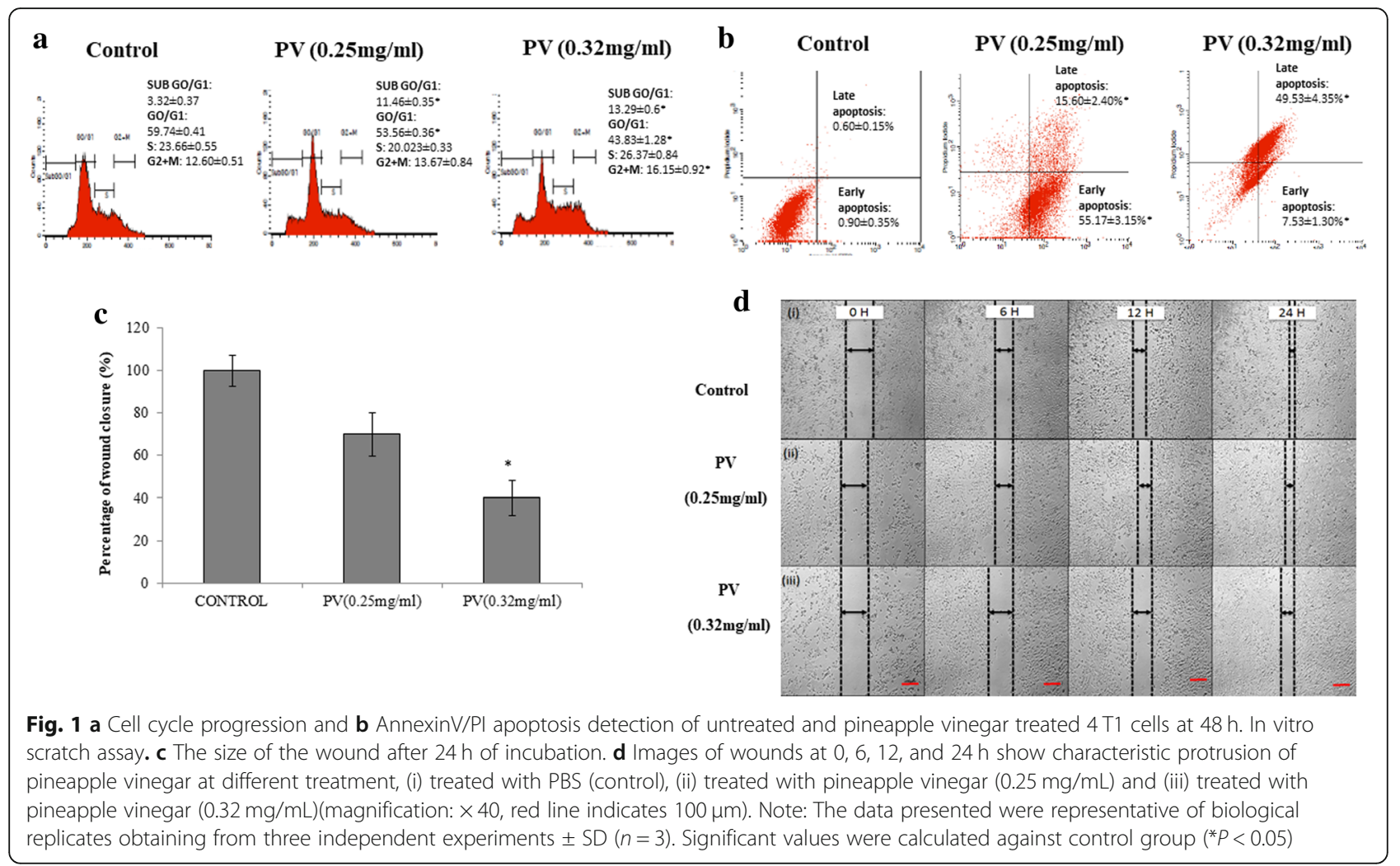

were displayed in Fig. 1b. In quadrant I (FITC negative, PI negative), a high population of viable cells was observed in the untreated control group $(98.40 \pm 0.22 \%)$. A significant increase in the early apoptosis cell population was observed in the quadrant II (FITC positive, PI negative) in the pineapple treated groups $(0.25 \mathrm{mg} / \mathrm{mL} \mathrm{PV}=55.17 \pm 0.24 \%$; 0.32 $\mathrm{mg} / \mathrm{mL} \mathrm{PV}=7.53 \pm 0.29 \%$ ). The treatment with $0.32 \mathrm{mg} /$ $\mathrm{mL}$ of pineapple vinegar showed a drastic increment $(49.54 \pm 0.95 \%)$ in the cell population in quadrant III (FITC negative, PI positive) and IV (FITC positive, PI positive) as compared to the $0.25 \mathrm{mg} / \mathrm{mL}$ of PV, which only induced $15.60 \pm 0.16 \%$ of $4 \mathrm{~T} 1$ cells under late apoptosis stage. These results imply that pineapple vinegar induced apoptosis in a dose dependent manner and as such, pineapple vinegar is a potent inducer of apoptosis and necrosis and could trigger events leading to apoptotic cell death.

\section{Pineapple vinegar inhibited the migration of $4 \mathrm{~T} 1$ cells in vitro}

The effect of pineapple vinegar in inhibiting the migration of $4 \mathrm{~T} 1$ cells was investigated through in vitro scratch assay. After $24 \mathrm{~h}$ of incubation, the rate of wound closure decreased as the dose increased (Fig. 1c and d). The pineapple vinegar was able to inhibit the closure of the scratch of $4 \mathrm{~T} 1$ cells to about $30 \%$ at the concentration of $0.25 \mathrm{mg} / \mathrm{mL}$ and around $60 \%$ at the concentration of $0.32 \mathrm{mg} / \mathrm{mL}$ at a time dependent manner.

\section{Pineapple vinegar inhibited the growth of tumor in vivo}

The anti-tumor activity of pineapple vinegar in mice was assessed using tumor weight data (Fig. 2a and b). Figure $2 \mathrm{~b}$ showed that the tumor weight was slightly lower (15.88\%) in PL group and significantly lower (43.60\%) in $\mathrm{PH}$ group as compared to the UT group.

\section{Pineapple vinegar induced apoptosis in tumor}

TUNEL assay was performed to study the apoptotic effect of pineapple vinegar in the tumor. Figure $2 \mathrm{c}$ showed that only TUNEL positive brown spots (DNA fragmentation) were observed in the UT group and the presence of TUNEL positive dark brown spots increased in the treatment groups as the concentration of the samples increased. The frequency of apoptotic events in mice was higher in $\mathrm{PH}$ group as compared to UT and PL groups (Fig. 2c).

\section{Pineapple vinegar enhanced the immunity in vivo}

As depicted in Fig. 3a, pineapple vinegar reduced the concentration of pro-inflammatory cytokines, IL-1 $\beta$ from $766.67 \pm 5.20 \mathrm{pg} / \mathrm{mL}$ (UT) to $466.67 \pm 3.20 \mathrm{pg} / \mathrm{mL}$ in $\mathrm{PL}$ group and $300.00 \pm 4.60 \mathrm{pg} / \mathrm{mL}$ in $\mathrm{PH}$. Similar trend was observed in the IL-10 level where a significant decrease was observed in the pineapple vinegar groups as compared to the UT group (UT $=555.56 \pm 3.40 \mathrm{pg} / \mathrm{mL}$; $\mathrm{PL}=483.33 \pm 7.20 \mathrm{pg} / \mathrm{mL} ; \quad \mathrm{PH}=477.54 \pm 5.40 \mathrm{pg} / \mathrm{mL})$. Conversely, significant increase of IL- 2 andIFN- $\gamma$ levels were observed in $\mathrm{PH}$ group where IL-2 level of $\mathrm{PH}$ 


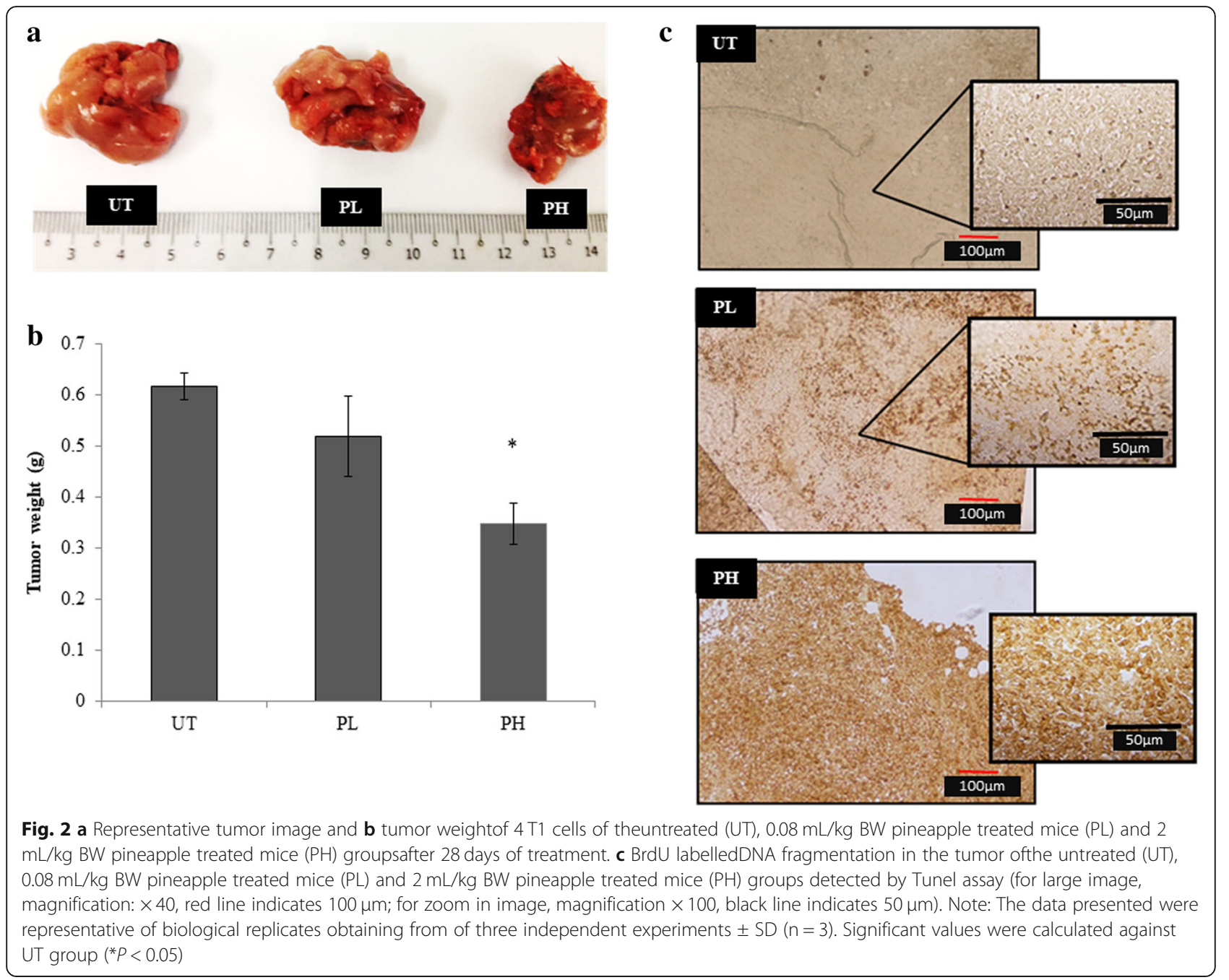

increased from $35.09 \pm 5.94 \mathrm{pg} / \mathrm{mL}$ in the UT group to $56.14 \pm 5.21 \mathrm{pg} / \mathrm{mL}$ and from $94.21 \pm 11.91$ in the UT group to $361.40 \pm 4.56 \mathrm{pg} / \mathrm{mL}$ for IFN- $\gamma$ level.

Immunophenotyping was done to further investigate the immunostimulatory effect of pineapple vinegar. As summarized in Fig. 3b, pineapple vinegar increased the level of $\mathrm{CD}^{+} / \mathrm{CD}^{+}, \mathrm{CD}^{+} / \mathrm{CD}^{+}$and both natural killer cell populations $\left(\mathrm{NK} 1.1^{+} / \mathrm{CD}^{+}\right.$ and $\mathrm{NK} 1.1^{+} / \mathrm{CD}^{-}$) and decreased the level of macrophage in the mouse splenocytes significantly. It was observed that the level of $\mathrm{CD}^{+} / \mathrm{CD}^{+}$was significantly increased in $\mathrm{PH}$ group from $14.25 \pm 0.04 \%$ (UT) to $17.14 \pm 0.29 \%(\mathrm{PH})$. A marked increment in the level of $\mathrm{CD}^{+} / \mathrm{CD}^{+}(\mathrm{UT}=3.12 \pm 0.20 \% ; \mathrm{PL}=$ $4.58 \pm 0.34 \% ; \mathrm{PH}=6.59 \pm 0.28 \%), \quad \mathrm{NK} 1.1^{+} / \mathrm{CD}^{-}(\mathrm{UT}=$ $1.39 \pm 0.04 \% ; \quad \mathrm{PL}=1.74 \pm 0.14 \% ; \quad \mathrm{PH}=1.91 \pm 0.01 \%)$, and $\quad \mathrm{NK} 1.1^{+} / \mathrm{CD}^{+} \quad(\mathrm{UT}=2.89 \pm 0.06 \% ; \quad \mathrm{PL}=3.92 \pm$ $0.31 \% ; \mathrm{PH}=6.82 \pm 0.09 \%)$ were demonstrated in both pineapple vinegar treatment groups as compared to the UT group. On the other hand, the level of macrophage was found to drop significantly when treated with pineapple vinegar (UT $=4.45 \pm 0.050 \%$; $\mathrm{PL}=3.03 \pm 0.10 \% ; \mathrm{PH}=3.01 \pm 0.10 \%$ ).

These results were further verified using a standard LDH cytotoxicity assay to quantify the cytotoxicity of the pineapple vinegar-treated and non-treated splenocytes against YAC-1 cells. Figure 3c showed that the exposure of splenocytes with Yac-1 cells at the ratio of 2 to 1 raised the cytotoxicity significantly to 53.34 and $58.70 \%$ for PL and PH groups respectively. The cytotoxicity was further increased when the number of splenocytes increased from 2 times to 5 times against the total cell number of YAC-1 cell.

\section{Pineapple vinegar regulated several inflammatory markers in vivo}

The ability of pineapple vinegar in reducing the inflammation in the tumors was investigated through the ability of the samples to decrease the level of nitric oxide (NO) and lipid peroxidation in tumor homogenate 

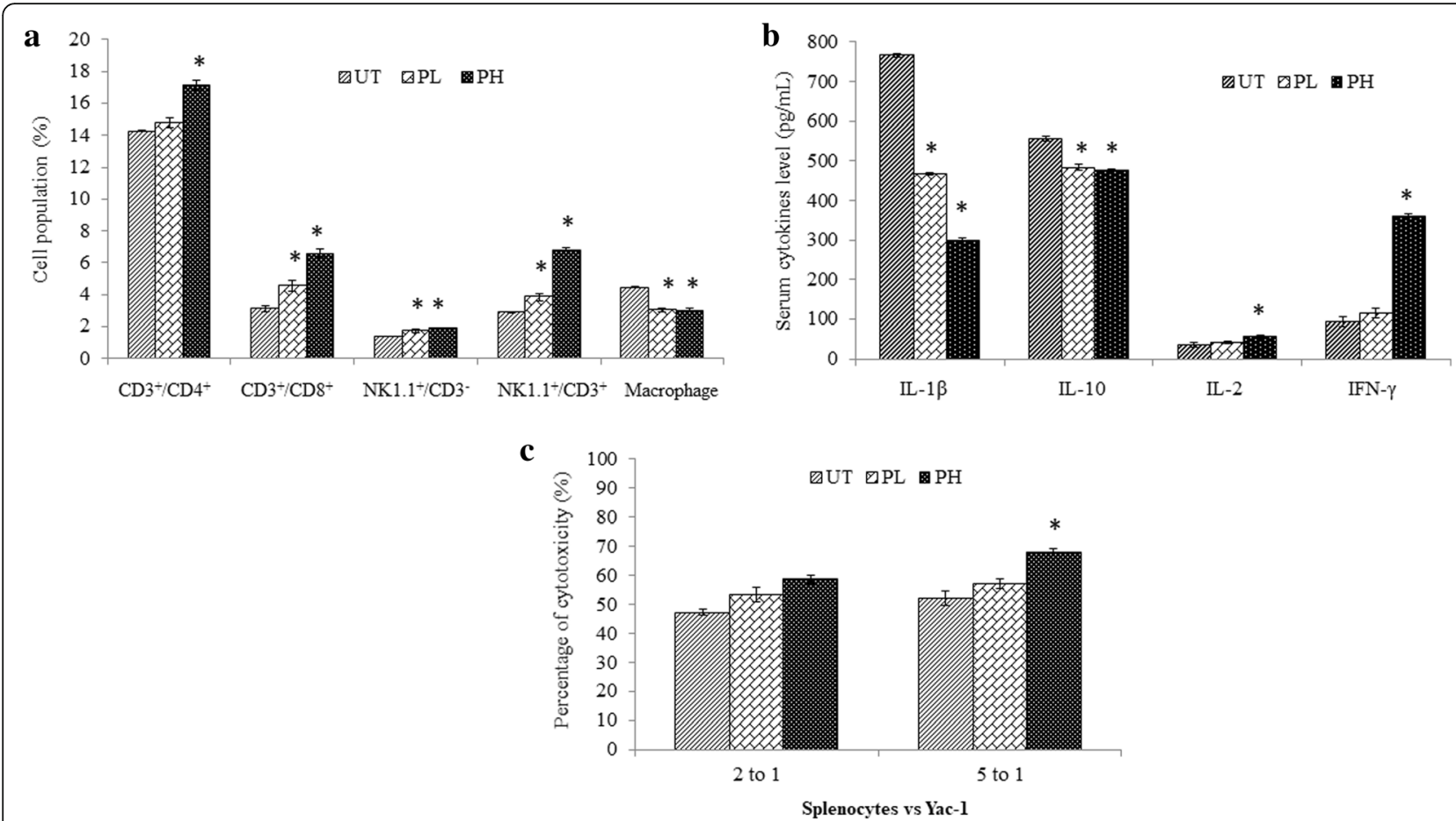

Fig. 3 a Flow cytometry immunophenotyping of $\mathrm{CD}^{+} / \mathrm{CD}^{+}, \mathrm{CD}^{+} / \mathrm{CD}^{+}, \mathrm{NK} 1.1^{+} / \mathrm{CD}^{-}, \mathrm{NK} 1.1^{+} / \mathrm{CD}^{+}$and macrophage population of splenocyte; b serum IL-1 $\beta, I L-10, I L-2$ and IFN- $\gamma$ cytokines level; c cytotoxicity of splenocytes against Yac-1 cells at ratio of 2 to 1 and 5 to 1 foruntreated (UT), $0.08 \mathrm{~mL} / \mathrm{kg}$ BW pineapple treated mice (PL) and $2 \mathrm{~mL} / \mathrm{kg} \mathrm{BW}$ pineapple treated mice (PH) after 28 days of treatment. Note: The data presented were representative of biological replicates obtaining from three independent experiments $\pm S D(n=3)$. Significant values were calculated against UT group $\left({ }^{*} P<0.05\right)$

samples. As depicted in Fig. 4a, pineapple vinegar treated groups were able to reduce the level of $\mathrm{NO}$ $(\mathrm{UT}=149.73 \pm 5.39 ; \quad \mathrm{PL}=125.74 \pm 4.18 ; \quad \mathrm{PH}=78.47 \pm$ $3.36 \mu \mathrm{M} \mathrm{NO} / \mathrm{mg}$ protein) and malonaldehyde (MDA) $(\mathrm{UT}=661.78 \pm 28.79 ; \mathrm{PL}=352.32 \pm 16.01 ; \mathrm{PH}=281.86 \pm$ $13.42 \mathrm{nM} \mathrm{MDA} / \mathrm{g}$ protein) significantly. The result was further investigated through the regulation of several inflammatory-related genes and they were demonstrated in Fig. 4b-d. Results showed that the treatment with pineapple vinegar was able to reduce the expressions of inducible nitric oxide synthases (iNOS) ( $\mathrm{PL}=1.2$ fold; $\mathrm{PH}=4$ fold) and nuclear factor kappa-light-chain-enhancer of activated $B$ cells $(\mathrm{NF}-\mathrm{k} \beta)(\mathrm{PL}=1.9$ fold; $\mathrm{PH}=3.5$ fold) genes as compared to the UT group (Fig. 4b) and inhibited the cyclooxygenase- $2(\mathrm{COX}-2)$ protein by 2 fold in $\mathrm{PH}$ group (Fig. $4 \mathrm{c}$ and $\mathrm{d}$ ).

\section{Pineapple vinegar inhibited the metastasis process in vivo}

To further elucidate the anti-metastasis effect of the pineapple vinegar, the bone marrow smearing assay and the clonogenic assay have been carried out. Figure 5a showed the invasion of the cancer cells into the bone marrow in the UT group while no abnormal cells was observed in the bone marrow of the treated groups. A similar pattern was observed in the clonogenic assay as depicted in Fig. 5b where only few colonies formed in the lungs of pineapple vinegar treatment group and no colonies were spotted in the other two organs (liver and spleen).

RT-PCR, western blot and proteome profiler were done to understand the effect of pineapple vinegar on the expression of genes involved in metastasis. Figure $4 b-d$ demonstrated the significant down-regulation of c-Myc (2.7 fold), intercellular adhesion molecule 1(ICAM-1) (5.9 fold), vascular endothelial growth factor (VEGF) (1.6 fold), and matrix metalloproteinases 9 (MMP9) (1.9 fold). Moreover, the regulation of several angiogenesis-related proteins is depicted in Fig. 6. From 18 angiogenesis proteins found to be regulated by pineapple vinegar, only 12 were significantly different. From the results, $\mathrm{PH}$ group showed a remarkable increase in interferon $\gamma$ induced protein $10 \mathrm{kDa}$ (IP-10) protein (IP-10 = 1.5 fold) and a significant decreased in several angiogenesis protein (cluster of differentiation 26 $(C D 26)=2.2$ fold; tissue inhibitors of metalloproteinases $1($ TIMP1 $)=3.4$ fold; P3 $=2.8$; hepatocyte growth factor $\quad(\mathrm{HGF})=2.9 ; \quad$ ENDOGLIN $=2.7 ; \quad$ CF3 = 3.3; matrix metalloproteinases $3(\mathrm{MMP}-3)=2.5$; insulinlike growth factor-binding protein 1 (IGFBP-1)=4.8; 
a
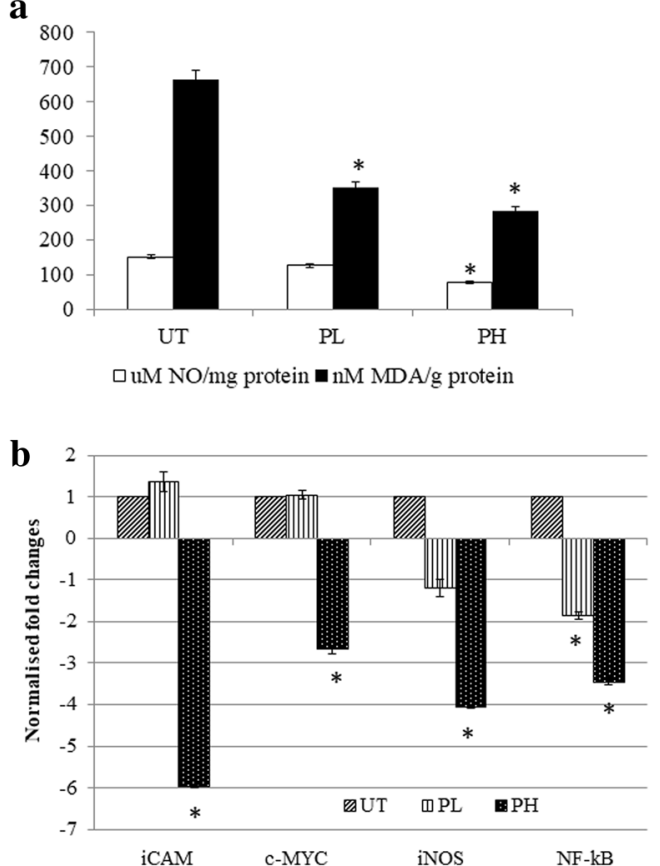

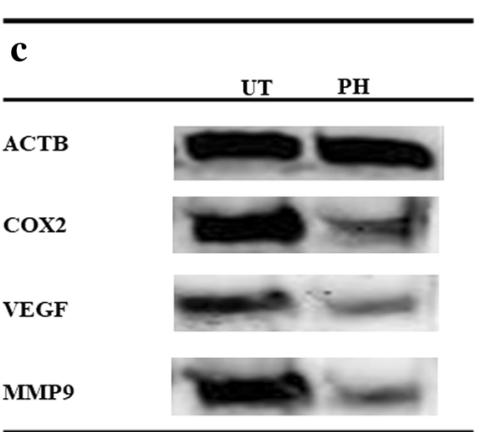

d

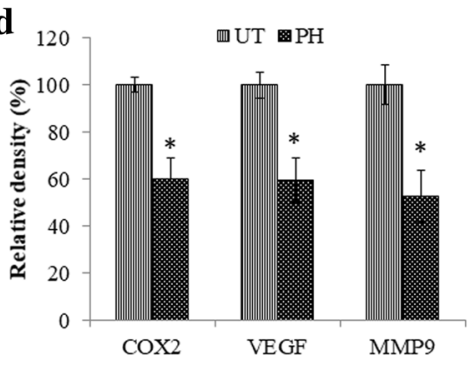

Fig. 4 a Tumor NO and MDA levels; $\mathbf{b}$ qPCR analyses on iCAM, c-MYC, iNOS and NF-kB genes in the tumor; c representative blot and $\mathbf{d}$ relative density for western blot analysis of COX2, VEGF and MMP9 protein expressions in the tumor of the untreated (UT) and $2 \mathrm{~mL} / \mathrm{kg}$ BW pineapple vinegar $(\mathrm{PH})$ in mice induced with 4T1 breast cancer cells. $\beta$-actin was used as reference protein. Note: The data presented were representative of biological replicates obtaining from three independent experiments $\pm S D(n=3)$. Significant values were calculated against UT group $\left({ }^{*} P<0.05\right)$
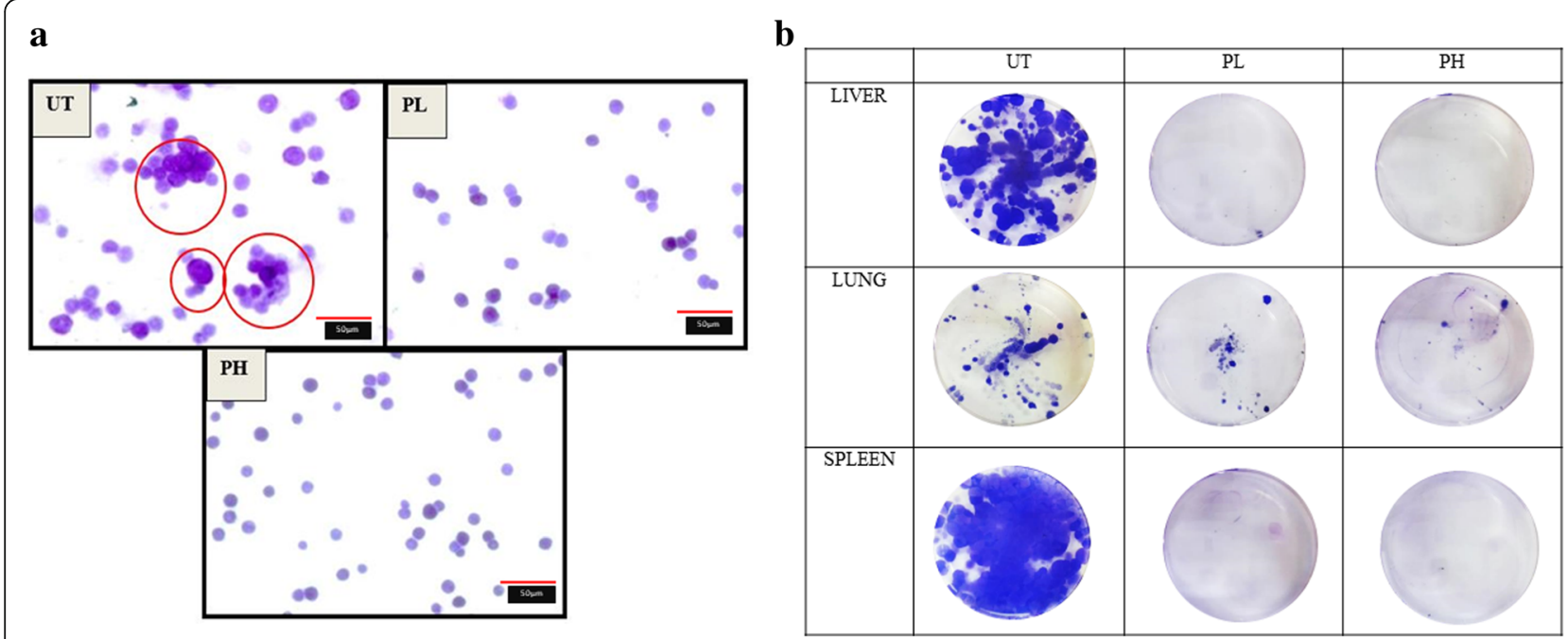

Fig. 5 Metastasis of 4 T1 cells to a bone marrow (magnification: $\times 100$, red line indicates $50 \mu \mathrm{m}$ ). Note: The data presented were representative of biological replicates obtaining from three independent experiments $\pm S D(n=3), \mathbf{b}$ lung, liver and spleen of untreated (UT), $0.08 \mathrm{~mL} / \mathrm{kg} B W$ pineapple treated mice $(\mathrm{PL})$ and $2 \mathrm{~mL} / \mathrm{kg}$ BW pineapple treated mice $(\mathrm{PH})$. Metastasis of $4 \mathrm{~T} 1$ cells to organs was measured by clonogenic assay. Circle $=$ metastatic cells in bone marrow smear 


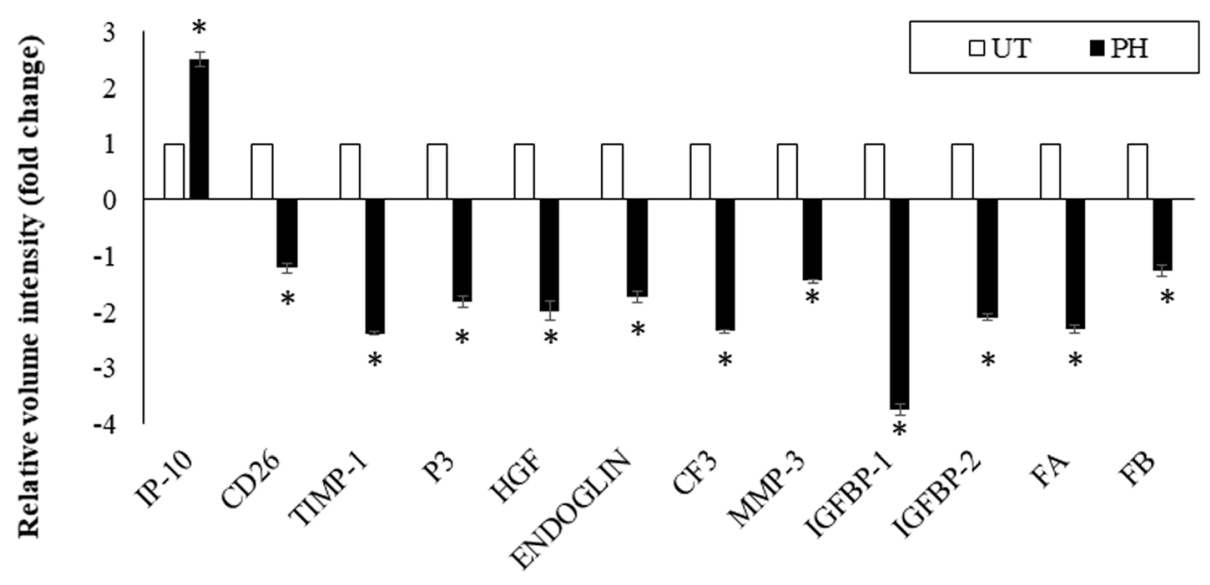

\begin{tabular}{|c|c|c|c|c|c|}
\hline \multirow{2}{*}{$: 8:$} & \multirow{2}{*}{ : $:$} & No & Analyte & No & Analyte \\
\hline & & 1 & SDF-1 & 10 & ENDOGLIN \\
\hline $2:=$ & & 2 & IP-10 & 11 & MIP-1 $\alpha$ \\
\hline$: 3 \quad 2:$ & $: 38=$ & 3 & $\mathrm{KC}$ & 12 & IGFBP-1 \\
\hline $2: 5$ & $=2: \mathrm{s}$ & 4 & CD26 & 13 & ENDOSTATIN \\
\hline 898 & $6>2990$ & 5 & ANGIOGENIN & 14 & MMP-3 \\
\hline 180 & $8_{1112}$ & 6 & TIMP-1 & 15 & IGFBP-2 \\
\hline $82:$ & $: 8^{\text {is }}{ }^{16}$ & 7 & $\begin{array}{l}\text { PENTRAXIN-3 } \\
\text { (P3) }\end{array}$ & 16 & $\begin{array}{l}\text { COAGULATION } \\
\text { FACTOR III (CF3) }\end{array}$ \\
\hline 8 is & & 8 & MCP-1 & 17 & FGF ACIDIC (FB) \\
\hline & & 9 & HGF & 18 & FGF BASIC (FA) \\
\hline
\end{tabular}

Fig. 6 Angiogenesis proteome assay of tumor in the untreated (UT) and $2 \mathrm{ml} / \mathrm{kg}$ BW pineapple treated mice (PH) groups. Note: The data presented were representative of biological replicates obtaining from three independent experiments $\pm S D(n=3)$. Significant values were calculated against UT group $(* P<0.05)$

insulin-like growth factor-binding protein 2 (IGFBP2) $=3.1 ; \mathrm{FA}=3.3 ; \mathrm{FB}=2.3$ )

\section{Discussion}

The chemoprevention via non-toxic agents could be a promising approach to prevent the incidence of cancer. Many naturally occuring agents have shown chemopreventive potential in a variety of bioassay systems and animal models [20]. Vinegar, on the other hand, has been utilized since ancient time as a cooking ingredient and folk medicine to treat many diseases such as cardiovascular disease and cancer [13-15]. Based on the in vitro and in vivo results presented in this study, it showed that pineapple vinegar possessed cytotoxic effect against 4 T1 cells and the pre-treatment with pineapple vinegar was able to reduce the tumor size significantly. These effects might be contributed through its ability to induce apoptosis, reduce inflammation and inhibit metastasis. Apoptosis is a programmed cell death that plays a significant role in cancer treatment [22]. The effect of pineapple vinegar to reduce the viability of $4 \mathrm{~T} 1$ breast cancer cells has been proven through the MTT screening result. The potential of pineapple vinegar to induce apoptosis was then verified through the cell cycle analysis and by detecting the externalization of phosphatidylserine using Annexin $\mathrm{V}$ analysis. In addition, in vivo TUNEL assay revealed the capability of pineapple vinegar to induce DNA fragmentation, animportant indicator of apoptosis execution process [22].

Immune suppression occurs frequently in cancer patient as the tumor cells normally inhibit the immune surveillance and reduce recognition by the immune cells [23]. T cells control the tumor progression by secreting pro-apoptotic cytokines [23]. Among those cytokines, IL-2 and IFN- $\gamma$ are known as anti-tumor cytokines, which help to execute cancer cells and activate $\mathrm{T}$ and NK cells cytotoxicity [24, 25]. The activation of IL-2 leads to the induction of IFN- $\gamma$ and the regulation of CD4+/CD3+ and CD8+/CD3 + cells by the activation of $\mathrm{T}$ helper cell [24]. The activation of these $\mathrm{T}$ helper, CD4+/CD3+, and CD8+/CD3 + cells may help to inhibit or delay the tumor progression. Based on the result, the increase of $\mathrm{CD} 4+/ \mathrm{CD} 3+, \mathrm{CD} 8+/ \mathrm{CD} 3+$ and $\mathrm{NK}$ cells in pineapple vinegar treatment groups were consistent with the increase of IL-2 and IFN- $\gamma$. This finding showed that the anti-tumor activity of pineapple vinegar may be contributed by the activation of cell mediated immunity by pineapple vinegar. 
Apart from the suppression of anti-tumor immunity, inflammation is always connected to the promotion of cancer cells proliferation. Therefore, the inhibition of the inflammation process is favorable in cancer treatment [26]. In this study, the effect of pineapple vinegar in reducing tumor inflammation has been investigated. During the tumor development, a pro-inflammatory microenvironment that favors the survival of cancer cell form around the tumors [26]. This condition primes the body immune system to produce pro-inflammatory cytokines such as IL-1 beta (IL-1 $\beta$ ) and subsequently activates NF- $\kappa \beta$ [27]. The activation of NF- $\kappa \beta$ promotes the up-regulation of COX-2 and iNOS, which subsequently promote the production of $\mathrm{NO}$ [27]. As the level of NO increases, the burden of the oxidative stress on the body is amplified and as a result, the body will release lipid peroxidative markers such as MDA. This severe inflammation was found to favor the progression of cancer as the inflammatory microenvironment serves to further potentiate tumor growth [26]. Based on the results, it was observed that the down-regulation of NF-k $\beta$ occurred concurrently with IL-1 $\beta$ and IL-10 depletion in the treated groups. The significant down-regulation of NF- $\mathrm{k} \beta$ also brought about the significant down-regulation in COX-2 and iNOS levels and the decrement in the production of NO and MDA in the treated groups as well.

$4 \mathrm{~T} 1$ cell is an aggressive and highly metastatic murine breast cancer cell line [28]. $4 \mathrm{~T} 1$ cells were able to metastasize into the bone marrow, liver, spleen and lung of the UT mice as shown in the bone marrow smearing and clonogenic assays. Conversely, the treatment with pineapple vinegar demonstrated an anti-metastasis effect as the number of colonies detected in the liver, lung and spleen of the pineapple vinegar-treated mice were decreased or not detected. These results supported the in vitro anti-migration and anti-invasion abilities of pineapple vinegar against $4 \mathrm{~T} 1$ cells. To understand the antimetastatic mechanism regulated by pineapple vinegar, the expression of c-Myc, ICAM-1, VEGF and MMP9, which are involved in the progression of cancer and highly expressed in cancer cells [29] were evaluated. A significant reduction in the expression of these genes was observed in both PH and PL groups. The inhibition of these genes may be resulted from the down-regulation of NF-k $\beta$ by pineapple vinegar as previous studies have shown a strong correlation between the regulation of the NF- $k \beta$ gene on several genes that involve in the metastasis processes including c-Myc, ICAM-1, VEGF and MMP9 [29].

Angiogenesis is one of the important steps in the metastasis process in breast cancer progression [30]. Based on the angiogenesis proteome profiler result, pineapple vinegar was able to significantly regulate several angiogenesis-related proteins such as IP10, CD26, TIMP-1, PENTRAXIN-3, HGF, ENDOGLIN, IGFBP-1 and -2, ENDOSTATIN, MMP-3, COAGULATION FACTOR III, fibroblast growth factor (FGF) acidic and basic. Previous study found that the activation of IFN $-\gamma$ helped to activate IP-10, one of the anti-tumor cytokines involves in the production of $\mathrm{T}$ cell and the inhibition of FGF production [31]. FGF promotes the tumor growth through the growth of new blood vessel [32]. In this study, the up-regulation of IP-10 and the down-regulation of FGF basic and acidic in the tumor of pineapple vinegar treated mice were strongly associated with the elevated level of IFN- $\gamma$ expression. Higher expression of CD26 has been reported in breast carcinoma study [33] while the expression of CD26 level was reduced significantly in the pineapple treatment group. CD26 is expressed by numerous cell types and plays an important role in the immune regulation but due to its unique characteristic, it has distinct roles in different cell type malignancies [33]. Additionally, pineapple vinegar was able to significantly down-regulate TIMP-1 and MMP9. TIMP-1 is a natural inhibitor of MMP9 and involves in the proliferation of cancer cells [34].

In addition, the pineapple vinegar treatment has significantly down-regulated the expressions of IGFBP-1 and IGFBP-2. Studies found that the over expression of IGFBPs level increased the risk of breast cancer through the proliferation process $[35,36]$. To note, the level of HGF also decreased significantly in the tumor of $\mathrm{PH}$ treated group. HGF promotes the tumor growth by stimulating neovascularization and it was found that the levels of HGF expression in breast cancer patients were elevated as compared to the normal people [37]. Moreover, the level of pentaxin-3 in the tumor of $\mathrm{PH}$ treated group decreased significantly. Pentraxin- 3 is one of the inflammatory signals induced by cytokines including IL-1 $\beta$ and the increase of pentraxin-3 was found to promote angiogenesis [38]. The expression of MMP-3 decreased significantly in pineapple vinegar treatment group. MMP-3 damages the extracellular matrix inhibitor, deactivates several proteinase inhibitors and increases the proliferation of cancer cells through fibrosis, neovascularization, and tenascin-C expression [39]. Additionally, the level of endoglin decreased significantly in pineapple vinegar treatment group. The over-expression of endoglin in the endothelial cell was found to promote the tumor growth through the proliferation process, increases the invasion and migration of cancer cells and promotes neovascularization [40].

In our previous study, we found that pineapple vinegar was rich in gallic acid $(862.61 \pm 4.38 \mu \mathrm{g} / \mathrm{mL})$, caffeic acid $(218.91 \pm 3.24 \mu \mathrm{g} / \mathrm{mL})$ and several other phenolic acids. There are many scientific evidences that implied the correlation between the polyphenol derived from fruits and vegetables with the anticancer property $[16,41]$. The chemo-preventive effect of pineapple vinegar through the anti-metastasis, anti-inflammatory and apoptosis 
activities may be strongly related to these bioactive compounds. Previous studies have shown that gallic acid inhibited the progression of several cancers via the suppression of metastasis and inflammation [16, 42-45]. Besides that, caffeic acid was also reported to induce apoptosis and inhibit metastasis and inflammation in previous studies [21, 46]. Thus, the anti-tumor effect of pineapple vinegar might be correlated with the high content of phenolic acids especially gallic and caffeic acid.

\section{Conclusion}

Pineapple vinegar showed an anti-tumor effect on 4 T1 cells in vitro and in vivo via the induction of apoptosis, inhibition of inflammation, suppression of tumor metastasis and activation of immune response. This study reflects a prominent effect of pineapple vinegar as a potential chemo-preventive dietry intervention for breast cancer. As cancer is a group of illnesses consisting various types of diseases [1], future study using other types of cancer cells are needed to evaluate this chemo-preventive effect across different types of cancer.

\section{Additional file}

Additional file 1: Table S1 Primer sequences. (DOCX 14 kb)

\section{Abbreviations}

CD26: Cluster of differentiation 26; cDNA: Complementary DNA; COX2: Cyclooxygenase-2; DAB: 3,3'-Diaminobenzidine; ELISA: Enzyme-linked immunosorbent assay; FACs: Fluorescence-activated cell sorter; FBS: Fetal bovine serum; FGF: Fibroblast growth factor; FITC: Fluorescein isothiocyanate; HGF: Hepatocyte growth factor; HRP: Horseradish peroxidase;

IACUC: Institutional Animal Care and Use Committees; ICAM-1: Intercellular Adhesion Molecule 1; IFN-y: Interferon gamma; IGFBP-1: Insulin-like growth factor-binding protein 1; IGFBP-2: Insulin-like growth factor-binding protein 2; IL-10: Interleukin-10; IL-1ß: Interleukin-1 beta; IL-2: Interleukin-2; iNOS: Inducible Nitric oxide synthases; IP-10: Interferon $\gamma$-induced protein $10 \mathrm{kDa}$; LDH: Lactate dehydrogenase; MDA: Malonaldehyde; MMP-3: Matrix metalloproteinases 3; MMP9: Matrix metalloproteinases 9; MTT: 3-(4,5-Dimethylthiazol-2-yl)-2,5diphenyltetrazolium bromide; NF-k $\beta$ : Nuclear factor kappa-light-chain-enhancer of activated $\mathrm{B}$ cells; $\mathrm{NH}_{4} \mathrm{Cl}$ : Ammonium chloride; $\mathrm{NO}$ : Nitric oxide; PBS: Phosphate buffer saline; $\mathrm{PH}$ : Pineapple vinegar high concentration; Pl: Propidium iodide; PL: Pineapple vinegar low concentration; RIPA: Radioimmunoprecipitation assay; RNA: Ribonucleic acid; RT-PCR: Real time polymerase chain reaction; SC: Subcutaneous; SDS: Sodium dodecyl sulfate; TBST: Tris-buffered saline (TBS) and Polysorbate 20; TdT: Terminal deoxynucleotidyl transferase; TIMP 1: Tissue inhibitors of metalloproteinases 1; TUNEL: Terminal deoxynucleotidyl transferase dUTP nick end labeling; UPM: Universiti Putra Malaysia; UT: in vivo untreated group; VEGF: Vascular endothelial growth factor

\section{Authors' contributions}

SAS and KL prepared and standardised the vinegar samples. NEM and SKYconceived and designed the experiments. NEM drafted the manuscript. NEM, NA, KLL, MFR and SKY participated in the experiments. NEM and NA carried out the data collection and analysis. SKY, MFR, KL and NBA reviewed the manuscript. All authors read and approved the final manuscript.

\section{Funding}

This study was supported by the grant from Pembangunan RMK10, Malaysian Agricultural Research and Development Institute (MARDI) and Research University Grant Scheme (Project No: 05-02-12-1718RU) provided by Universiti Putra Malaysia, Malaysia. The funder has no role/influence in this study.

Availability of data and materials

All relevant data and materials are within the manuscript.

\section{Ethics approval}

This study was carried out in strict accordance with the guideline for the Institutional Animal Care and Use Committee, Universiti Putra Malaysia (UPM/IACUC/AUP-R097/2014).

\section{Consent for publication}

Not Applicable.

\section{Competing interests}

The authors declare that they have no competing interests.

\section{Author details}

'Department of Cell and Molecular Biology, Faculty of Biotechnology and Biomolecular Science, Universiti Putra Malaysia (UPM), 43400 Serdang, Selangor, Malaysia. ${ }^{2}$ UKM Molecular Biology Institute (UMBI), UKM Medical Centre, Jalan Yaa'cob Latiff, Bandar Tun Razak, 56000 Cheras, Kuala Lumpur, Malaysia. ${ }^{3}$ China-ASEAN College of Marine Sciences, Xiamen University Malaysia, Jalan Sunsuria, Bandar Sunsuria, 43900 Sepang, Selangor, Malaysia. ${ }^{4}$ Faculty of Medicine and Health Sciences, Universiti Tunku Abdul Rahman, Sungai Long Campus, Jalan Sungai Long, Bandar Sungai Long, Cheras, 43000 Kajang, Selangor, Malaysia. ${ }^{5}$ Biotechnology Research Centre, Malaysian Agricultural Research and Development Institute (MARDI), 43400 Serdang, Selangor, Malaysia. ${ }^{6}$ Institute of Bioscience, Universiti Putra Malaysia (UPM), 43400 Serdang, Selangor, Malaysia.

Received: 12 April 2019 Accepted: 23 July 2019

Published online: 26 July 2019

\section{References}

1. Pandey G, Madhuri S. Some medicinal plants as natural anticancer agents. 2009;3:259-63.

2. Arif Hasan S, Mahtab Uddin M, Nazib-ul Huda K, Das A, Tabassum N, Rafat Hossain $\mathrm{M}$, et al. Ethnomedicinal plants of two village folk medicinal practitioners in Rajshahi District, Bangladesh: comparison of their folk medicinal uses with Ayurvedic uses. Am J Sustain Agric. 2014;8:10-9.

3. Khazir J, Mir BA, Pilcher L, Riley DL. Role of plants in anticancer drug discovery. Phytochem Lett. 2014;7:173-81.

4. Yang $\mathrm{MH}$, Kim J, Khan IA, Walker LA, Khan SI. Nonsteroidal antiinflammatory drug activated gene-1 (NAG-1) modulators from natural products as anti-cancer agents. Life Sci. 2014;100:75-84.

5. Schieber A, Stintzing F, Carle R. By-products of plant food processing as a source of functional compounds - recent developments. Trends Food Sci Technol. 2001;12:401-13.

6. Tacar O, Sriamornsak P, Dass CR. Doxorubicin: an update on anticancer molecular action, toxicity and novel drug delivery systems. J Pharm Pharmacol. 2013:65:157-70.

7. Siegel R, Ma J, Zou Z, Jemal A. Cancer statistics, 2014. CA Cancer J Clin. 2014;64:9-29.

8. National Institutes of Health Consensus Development Conference Statement. Adjuvant therapy for breast Cancer, November 1-3, 2000. JNCI Monogr. 2001;2001:5-15.

9. Lam KS. New aspects of natural products in drug discovery. Trends Microbiol. 2007;15:279-89.

10. Tochi BN, Wang Z, Xu S-Y, Zhang W. Therapeutic application of pineapple protease (bromelain): a review. Pakistan J Nutr. 2008;7:513-20.

11. Johnston C, Gaas C. Vinegar: medicinal uses and antiglycemic effect. Medscape Gen Med. 2006:8:61.

12. Mohamad NE, Yeap SK, Lim KL, Yusof HM, Beh BK, Tan SW, et al. Antioxidant effects of pineapple vinegar in reversing of paracetamol-induced liver damage in mice. Chinese Med (United Kingdom). 2015;10:1-14.

13. Shimoji $Y$, Kohno H, Nanda K, Nishikawa Y, Ohigashi H, Uenakai K, et al. Extract of Kurosu, a vinegar from unpolished rice, inhibits azoxymethane-induced colon carcinogenesis in male F344 rats. Nutr Cancer. 2004;49:170-3.

14. Shimoji Y, Sugie $S$, Kohno H, Tanaka T, Nanda K, Tamura Y, et al. Extract of vinegar "Kurosu" from unpolished rice inhibits the development of colonic 
aberrant crypt foci induced by azoxymethane. J Exp Clin Cancer Res. 2003; 22:591-7.

15. Mimura A, Suzuki Y, Toshima Y, Yazaki S-I, Ohtsuki T, Ui S, et al. Induction of apoptosis in human leukemia cells by naturally fermented sugar cane vinegar (kibizu) of Amami Ohshima Island. BioFactors. 2004;22:93-7.

16. Liu RH. Potential synergy of phytochemicals in cancer prevention: mechanism of action. J Nutr. 2004;134:3479S-85S.

17. Weng CJ, Yen GC. Chemopreventive effects of dietary phytochemicals against cancer invasion and metastasis: phenolic acids, monophenol, polyphenol, and their derivatives. Cancer Treat Rev. 2012;38:76-87.

18. Roleira FMF, Tavares-da-Silva EJ, Varela CL, Costa SC, Silva T, Garrido J, et al. Plant derived and dietary phenolic antioxidants: anticancer properties. Food Chem. 2015;183:235-58.

19. Nishidai S, Nakamura Y, Torikai K, Yamamoto M, Ishihara N, Mori H, Ohigashi H. Kurosu, a traditional vinegar produced from unpolished rice, suppresses lipid peroxidation in vitro and in mouse skin. Biosci Biotechnol Biochem. 2000;64(9):1909-14.

20. Abu N, Mohamed NE, Yeap SK, Lim KL, Akhtar MN, Zulfadli AJ, et al. In vivoantitumor and antimetastatic effects of flavokawain B in 4T1 breast cancer cell-challenged mice. Drug Des Devel Ther. 2015;9:1401-17.

21. Rosendahl AH, Perks CM, Markkula A, Simonsson M, Rose CC, Ingvar C, et al. Abstract 4685: caffeine and caffeic acid inhibit growth and modify estrogen receptor (ER)-a and insulin-like growth factor I receptor (IGF-IR) levels in human breast cancer. Cancer Res. 2014;74:4685.

22. Kerr JFR, Winterford CM, Harmon BV. Apoptosis. Its significance in cancer and cancer therapy. Cancer. 1994;73:2013-26.

23. Whitehead RH, Thatcher J, Teasdale C, Roberts GP, Hughes LE. T and B lymphocytes in breast cancer stage relationship and abrogation of Tlymphocytes depression by enzyme treament in vitro. Lancet. 1976;307:330-3.

24. Kasahara T, Hooks JJ, Dougherty SF, Oppenheim JJ. Interleukin 2-mediated immune interferon (IFN-gamma) production by human T cells and T cell subsets. J Immunol. 1983;130:1784-9.

25. Vivier E, Tomasello E, Baratin M, Walzer T, Ugolini S. Functions of natural killer cells. Nat Immunol. 2008:9:503-10.

26. Candido J, Hagemann T. Cancer-related inflammation. J Clin Immunol. 2013; 33(Suppl 1):S79-84.

27. Jung Y-J, Isaacs JS, Lee S, Ttrepel J, Neckers L. IL-1 $\beta$-mediated up-regulation of HIF-1a via an NFkB/COX-2 pathway identifies HIF-1 as a critical link between inflammation and oncogenesis. FASEB J. 2003;17:2115-7.

28. Gao Z-G, Tian L, Hu J, Park I-S, Bae YH. Prevention of metastasis in a 4T1 murine breast cancer model by doxorubicin carried by folate conjugated pH sensitive polymeric micelles. J Control Release. 2011;152:84-9.

29. Aggarwal BB. Nuclear factor-KB: the enemy within. Cancer Cell. 2004;6:203-8.

30. Longatto Filho A, Lopes JM, Schmitt FC. Angiogenesis and breast cancer. J Oncol. 2010;2010:576384

31. Burkholder B, Huang R-Y, Burgess R, Luo S, Jones VS, Zhang W, et al. Tumor-induced perturbations of cytokines and immune cell networks. Biochim Biophys Acta - Rev Cancer. 1845;2014:182-201.

32. Yoshimura N, Sano H, Hashiramoto A, Yamada R, Nakajima H, Kondo M, et al. The expression and localization of fibroblast growth factor-1 (FGF-1) and FGF receptor-1 (FGFR-1) in human breast cancer. Clin Immunol Immunopathol. 1998;89:28-34.

33. Erić-Nikolić A, Matić IZ, Đorđević M, Milovanović Z, Marković I, Džodić R, et al. Serum DPPIV activity and CD26 expression on lymphocytes in patients with benign or malignant breast tumors. Immunobiology. 2011;216:942-6.

34. Wu Z-S, Wu Q, Yang J-H, Wang H-Q, Ding X-D, Yang F, et al. Prognostic significance of MMP-9 and TIMP-1 serum and tissue expression in breast cancer. Int J Cancer. 2008;122:2050-6.

35. Endogenous Hormones and Breast Cancer Collaborative Group TEH and BCC Key TJ, Appleby PN, Reeves GK, Roddam AW. Insulin-like growth factor 1 (IGF1), IGF binding protein 3 (IGFBP3), and breast cancer risk: pooled individual data analysis of 17 prospective studies. Lancet Oncol. 2010;11:530-42.

36. Baxter RC. IGF binding proteins in cancer: mechanistic and clinical insights. Nat Rev Cancer. 2014;14:329-41.

37. Martin TA, Parr C, Davies G, Watkins G, Lane J, Matsumoto K, et al. Growth and angiogenesis of human breast cancer in a nude mouse tumour model is reduced by NK4, a HGF/SF antagonist. Carcinogenesis. 2003;24:1317-23.

38. Margheri F, Serrati S, Lapucci A, Anastasia C, Giusti B, Pucci M, et al. Systemic sclerosis-endothelial cell antiangiogenic pentraxin 3 and matrix metalloprotease 12 control human breast cancer tumor vascularization and development in mice. Neoplasia. 2009;11:1106-15.
39. Duffy MJ, Maguire TM, Hill A, McDermott E, O'Higgins N. Metalloproteinases: role in breast carcinogenesis, invasion and metastasis. Breast Cancer Res. 2000;2:252-7.

40. Oxmann D, Held-Feindt J, Stark AM, Hattermann K, Yoneda T, Mentlein R. Endoglin expression in metastatic breast cancer cells enhances their invasive phenotype. Oncogene. 2008;27:3567-75.

41. Cai Y, Luo Q, Sun M, Corke H. Antioxidant activity and phenolic compounds of 112 traditional Chinese medicinal plants associated with anticancer. Life Sci. 2004;74:2157-84.

42. Hsu J-D, Kao S-H, Ou T-T, Chen Y-J, Li Y-J, Wang C-J. Gallic acid induces G2/ $M$ phase arrest of breast cancer cell MCF-7 through stabilization of p27 ${ }^{\text {Kip }}$ attributed to disruption of p27 Kip1/Skp2 complex. J Agric Food Chem. 2011:59:1996-2003

43. Faried A, Kurnia D, Faried LS, Usman N, Miyazaki T, Kato H, et al. Anticancer effects of gallic acid isolated from Indonesia herbal medicine, Phaleria macrocarpa (Scheff.) Boerl, on human cancer cell lines. Int J Oncol. 2007:30:605-13.

44. Ho H-H, Chang C-S, Ho W-C, Liao S-Y, Wu C-H, Wang C-J. Anti-metastasis effects of gallic acid on gastric cancer cells involves inhibition of NF-KB activity and downregulation of PI3K/AKT/small GTPase signals. Food Chem Toxicol. 2010;48:2508-16.

45. Kawada M, Ohno Y, Ri Y, Ikoma T, Yuugetu H, Asai T, et al. Anti-tumor effect of gallic acid on LL-2 lung cancer cells transplanted in mice. Anti-Cancer Drugs. 2001;12:847-52

46. Aravind SR, Joseph MM, Varghese S, Balaram P, Sreelekha T. Antitumor and immunopotentiating activity of polysaccharide PST001 isolated from the seed kernel of Tamarindus indica : an in vivostudy in mice. Sci World J. 2012;2012:1-14.

\section{Publisher's Note}

Springer Nature remains neutral with regard to jurisdictional claims in published maps and institutional affiliations.

Ready to submit your research? Choose BMC and benefit from:

- fast, convenient online submission

- thorough peer review by experienced researchers in your field

- rapid publication on acceptance

- support for research data, including large and complex data types

- gold Open Access which fosters wider collaboration and increased citations

- maximum visibility for your research: over $100 \mathrm{M}$ website views per year

At $\mathrm{BMC}$, research is always in progress.

Learn more biomedcentral.com/submissions 